\title{
Morphological and ecological characterization of Batrachospermales (Rhodophyta) in the Jarama Basin, Iberian Peninsula
}

\author{
Javier Carmona ${ }^{1}$, Elvira Perona ${ }^{2, *}$, Elena Sánchez-Díaz ${ }^{2}$ and Virginia Loza ${ }^{2}$
}

${ }^{1}$ Departamento de Ecología y Recursos Naturales. Facultad de Ciencias. Universidad Nacional Autónoma de México. Circuito exterior s/n. Ciudad Universitaria, Coyoacán 04510. Mexico D.F. jcj@hp.fciencias.unam.mx

${ }^{2}$ Departamento de Biología. Facultad de Ciencias. Universidad Autónoma de Madrid. Edificio de Biología. C/ Darwin, 2. Ciudad Universitaria de Cantoblanco. 28049. Madrid. Spain.

*Corresponding author: elvira.perona@uam.es

Received: 22/4/10

Accepted: 14/3/11

\begin{abstract}
Morphological and ecological characterization of Batrachospermales (Rhodophyta) in the Jarama Basin (Iberian Peninsula)

Five populations of freshwater red algae were investigated between February 2008 and September 2009 in four segments of the Jarama River Basin (Tajo Basin), Iberian Peninsula, between $40-41^{\circ} \mathrm{N}, 3-4^{\circ} \mathrm{W}$, at 700 to $1200 \mathrm{~m}$ altitude. Three species were documented (Batrachospermum gelatinosum, Lemanea fluviatilis and Paralemanea catenata) and information was collected about includes their morphology and the physical and chemical characteristics of the water. All the taxa have been reported previously, but the present work includes the first detailed morphological description of red algae in the region and their ecological preferences. The waters in these study sites are cool to temperate $\left(5-17^{\circ} \mathrm{C}\right)$, acid to circumneutral $(\mathrm{pH} 6.3-7.5)$ and with a low ion concentration (specific conductivity $77-270 \mu \mathrm{S} \mathrm{cm}^{-1}$ ). Two groups were distinguished on the basis of nutrient concentration. The first group, which included B. gelatinosum and L. fluviatilis, is found in clean water with low nutrient concentration, while the second group, which included $P$. catenata, occurred in nutrient-rich water. Gametophytes of $L$. $f l u$ viatilis and $P$. catenata were present in all seasons, with the highest percentage cover in autumn and winter corresponding to high current velocity and low water temperature. However, gametophytes were longest, and spermatangial sori and carposporophytes were most abundant in spring when current velocity was low and water temperature was high. The distribution of Batrachosermales from the Jarama Basin showed a strong affinity with temperate regions of central Europe and floras of other continents.
\end{abstract}

Key words: Batrachospermales, central Iberian Peninsula, ecology, flora, Rhodophyta, streams.

\section{RESUMEN}

Caracterización morfologica y ecológica de Batrachospermales (Rhodophyta) en la cuenca del Jarama (Península Ibérica)

Se han estudiado cinco poblaciones de algas rojas de agua dulce durante el periodo de febrero 2008 a septiembre 2009, en cuatro segmentos de la cuenca del río Jarama (Cuenca del Tajo), Península Ibérica, entre latitudes $\left(40-41^{\circ} \mathrm{N}, 3-4^{\circ} \mathrm{O}\right)$ y 700 a $1200 \mathrm{~m}$ de altitud. Se describe la morfología de 3 especies (Batrachospermum gelatinosum, Lemanea fluviatilis and Paralemanea catenata) junto con sus características físico-químicas del agua. Todos los taxones encontrados han sido ya citados, sin embargo el presente trabajo incluye la primera descripción morfológica detallada de algas rojas en la región y sus preferencias ecologicas. Las zonas de estudio presentan aguas frías a templadas $\left(5-17^{\circ} \mathrm{C}\right)$, acidas a neutrales (6.3-7.5) y relativamente baja concentración de iones (conductividad específica $77-270 \mu \mathrm{S} \mathrm{cm}{ }^{-1}$ ). En función de la concentración de nutrientes se pueden distinguir 2 grupos. El primero, que incluye B. gelatinosum y L. fluviatilis, se encuentra en aguas con baja concentración de nutrientes, mientras que el otro grupo que contiene P. catenata aparece en aguas ricas en nutrientes. Los gametofitos de L. fluviatilis y P. catenata estuvieron presentes durante todas las estaciones del año, con la mayor cobertura porcentual en otoño e invierno y corresponden con la mayor velocidad de corriente y baja temperatura del agua. Sin embargo, el largo del gametofito, el número de soros espermatangiales y el número de carposporofitos fue mayor en primavera con la mayor temperatura del agua y la más baja velocidad de corriente. La distribución de las Batrachospermales en la cuenca del río Jarama, mostraron una fuerte afinidad con regiones templadas de Centroeuropa y otros continentes.

Palabras clave: Batrachospermales, ecología, flora, Península Ibérica, Rhodophyta, ríos. 


\section{INTRODUCTION}

The red algal order Batrachospermales is a major group of freshwater Rhodophyta that occurs widely in lotic ecosystems throughout the world (Sheath \& Hambrook, 1990). In Europe, the most red algae taxa live in running waters (Kwandrans \& Eloranta, 2010). They have a heteromorphic triphasic life history consisting of a gametophyte (monoecious and/or dioecious), which produces spermatangia in clusters, carpogonia with elongated trichogynes and the "Chantransia" stage (sporophyte), which consists of tuft-shaped filaments that produce new gametophytes through vegetative meiosis (Sheath, 1984; Sheath et al., 1996; Necchi \& Carmona, 2002). Several morphological and reproductive adaptations of this species have been associated with the high current velocity in lotic ecosystems (Coomans \& Hommersand, 1990; Carmona et al., 2006; Carmona et al., 2009). Three families are recognized in the order and can be distinguished as follows (based on Kumano, 1993; Sheath et al., 1996). Batrachospermaceae includes algae with uniaxial and corticated cells, determinate growth in the verticilated filaments and extracellular sheath. Psilosiphonaceae has a pseudoparenchymatous structure and densely interwoven medullary filaments. Lemaneaceae has a pseudoparenchymatous thallus with interwoven medullary filaments absent. The Batrachospermaceae and Lemaneaceae family are common in running waters and have a world-wide distribution (Eloranta \& Kwandrans, 2002), while Psilosiphonaceae are confined to freshwater streams from Australia (Entwisle, 1989).

Some studies of red algae have also been done in the north (Lopez \& Peñalta, 2004) and east of the Iberian Peninsula (Tomas et al., 1987; Aboal, 1989; Prefasi \& Aboal, 1994), and there are some reports from the west and centre of the Peninsula (Reis, 1954, 1962a, 1962b, 1965, 1973). When Biological Quality Control Network using macrophytes has been carried out in the Tajo river Basin, Batrachospermum and Lemanea genera have been found in siliceous rivers and streams but Paralemanea have not been detected (Confederación Hidrográfica del Tajo, 2009). Sabater et al. (1989) reported three species of Batrachospermales with a wider distribution in the Iberian Peninsula. Batrachospermum gelatinosum (= B. moniliforme, Batrachospermaceae) is tolerant of a wide range of physical and chemical conditions of water, followed by Lemanea fluviatilis (Lemaneaceae) and Paralemanea catenata $(=L e-$ manea nodosa) (Lemaneaceae), which presented a range of restricted sites with low mineralization and high flow water. This paper seeks to contribute to the knowledge of the detailed anatomical and environmental characteristics of the Batrachospermales populations in the Jarama Basin, Iberian Peninsula.

\section{MATERIALS AND METHODS}

The geomorphological conditions of the Jarama Basin encompass the large granite-dominated highlands where our sampling sites are located (Guadarrama Mountains, Sierra de Guadarrama, Spain). They are dominated by uplifted blocks of siliceous materials from the Tertiary period (Gibbons \& Moreno, 2006). Climatologically it is a typical continental Mediterranean climate in high mountains characterized by cold winters and high summer temperatures, at least $80 \%$ of the rain falls during the three winter months. Some headwaters sites, located in high altitude areas, are characterized by extreme wet and cold (Gasith \& Resh, 1999). The area has favoured the formation of coniferous and oaks forest and streams with relatively cold waters (Carranza $\&$ Arístegui, 2002). The populations of Batrachospermales analysed in this study were collected from four segments of the Jarama Basin (Fig. 1), the Guadalix and Manzanares rivers and the Mediano stream $\left(40-41^{\circ} \mathrm{N}, 3-4^{\circ} \mathrm{W}\right)$ at altitudes from 900 to $1200 \mathrm{~m}$. Temperature and $\mathrm{pH}$ were measured with a WTW pH-96 electrode, specific conductance was measured with a CRISON CDTM523 conductivity meter and oxygen was measured with a WTW oxi-196 Oxygen meter. To investigate water chemistry, one-litre samples were taken and calcium and nutrient concentrations were analyzed in the field within one hour of collection using a DRELL 2010 portable 


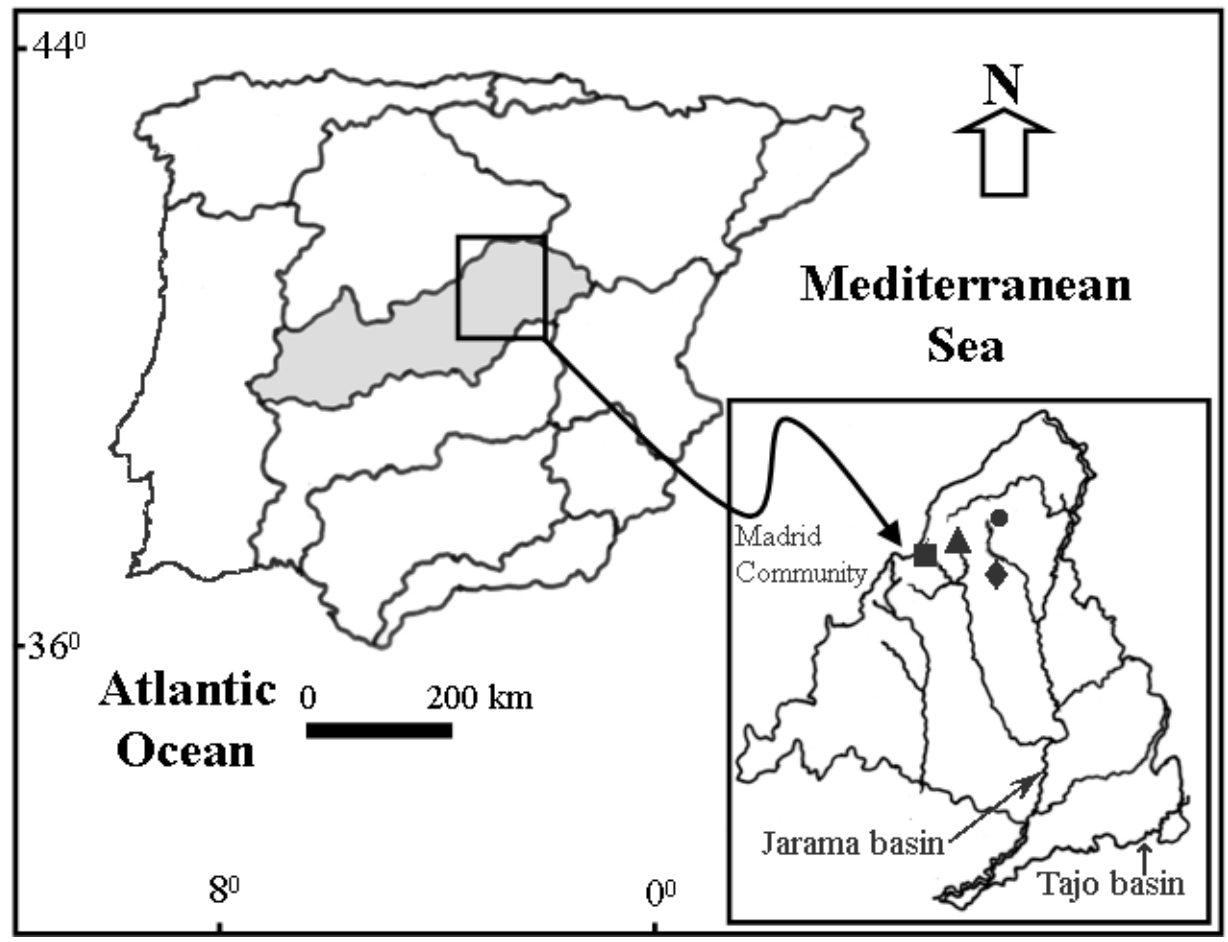

Figure 1. Distribution of Batrachospermales populations in Jarama Basin populations, Iberian Peninsula (Tajo Basin in grey). - Guadalix 1 (Batrachospermum gelatinosum and Lemanea fluviatilis), Guadalix 2 (Paralemanea catenata), $\Delta$ Manzanares (L. fluviatilis), - Mediano (L. fluviatilis). Distribución de las poblaciones de Batrachospermales en la cuenca de Jarama, Península Ibérica (Cuenca del Tajo, en gris) • Guadalix 1 (Batrachospermum gelatinosum and Lemanea fluviatilis), $\downarrow$ Guadalix 2 (Paralemanea catenata), ৯ Manzanares (L. fluviatilis), Mediano (L. fluviatilis).

laboratory (Hach Company). These analyses are adapted from Standard Methods for the Examination of Water and Wastewater (APHA, 1995) and have been previously described by Douterelo et al. (2004). Calcium was estimated volumetrically with a Cal Ver 2 Calcium indicator (detection limit $10 \mathrm{mg} \mathrm{l}^{-1}$ ), titrating with 0.08M EDTA in alkaline medium. Dissolved inorganic nitrogen (DIN) was calculated as the sum of the three inorganic nitrogen forms in water. $\mathrm{NH}_{4}-\mathrm{N}$ was measured colorimetrically by the Nessler method (detection limit $0.1 \mathrm{mg} \mathrm{l}^{-1}$ ), reading the absorbance at $425 \mathrm{~nm}$. When values were close to the detection limits, the salicylate method was used (detection limit $0.01 \mathrm{mg} \mathrm{l}^{-1}$ ), read at $655 \mathrm{~nm}$. $\mathrm{NO}_{3}-\mathrm{N}$ was measured colorimetrically by a modification of the cadmium reduction method, using gentisic acid instead of 1-naphthylamine (detection limit $0.5 \mathrm{mg} \mathrm{l}^{-1}$ ) and reading absorbance at $500 \mathrm{~nm}$. The low-range method (up to $0.5 \mathrm{mg} \mathrm{l}^{-1}$ ) is an expanded modification of the former that employs a chromotropic acid indicator (detection limit $0.05 \mathrm{mg} \mathrm{l}^{-1}$ ) reading at the same wavelength. $\mathrm{NO}_{2}-\mathrm{N}$ was determined colorimetrically using chromotropic and sulphanilic acids as indicators (detection limit $0.01 \mathrm{mg} \mathrm{l}^{-1}$ ) and reading absorbance at $500 \mathrm{~nm}$. $\mathrm{PO}_{4}^{3}-\mathrm{P}$ was estimated colorimetrically with a modification of the molybdenum blue procedure, provided by Phos Ver 3 (detection limit $0.01 \mathrm{mg} \mathrm{l}^{-1}$ ), reading absorbance at $890 \mathrm{~nm}$. All these were measured in triplicate.

Biological characteristics of all populations were analyzed at least in triplicate. Percentage cover was estimated using the quadrant technique (Necchi et al., 1995). Each sampling unit was a circle of $10 \mathrm{~cm}$ radius (area $314 \mathrm{~cm}^{2}$ ). Microhabitat variables were measured in situ at the centre of each population $(n=10)$ : current velocity and irradiance were measured as close to the alga as possible, using an FP 101-201 Global Wa- 
ter Flow Probe and a Quantum Photoradiometer Delta OHM-HD9021 with an LP9021 sensor in the photosynthetically active radiation spectral range (PAR). Biological samples were preserved in $3 \%$ formaldehyde and included in the herbaria of the Faculty of Science from Mexico "María Agustina Batalla" (FCME, Holmgren et al., 1990). We have taken into account all the quantitative and qualitative morphological characters previously considered to be of taxonomic and reproductive importance at the generic and specific levels in previous relevant studies (Vis \& Sheath, 1992, 1996, 1998; Vis et al., 1995; Sheath et al., 1996; Carmona \& Necchi, 2002; Filkin \& Vis, 2004; Kučera \& Marvan, 2004; Carmona \& Vilaclara, 2007). For microscopic analyses and photographic documentation of cytological characters, we used an Olympus BX51 microscope equipped with an SC35 microphotography system. Morphometric characters were measured in 20 replicates per population on each sampling date; the number of replicates was de-

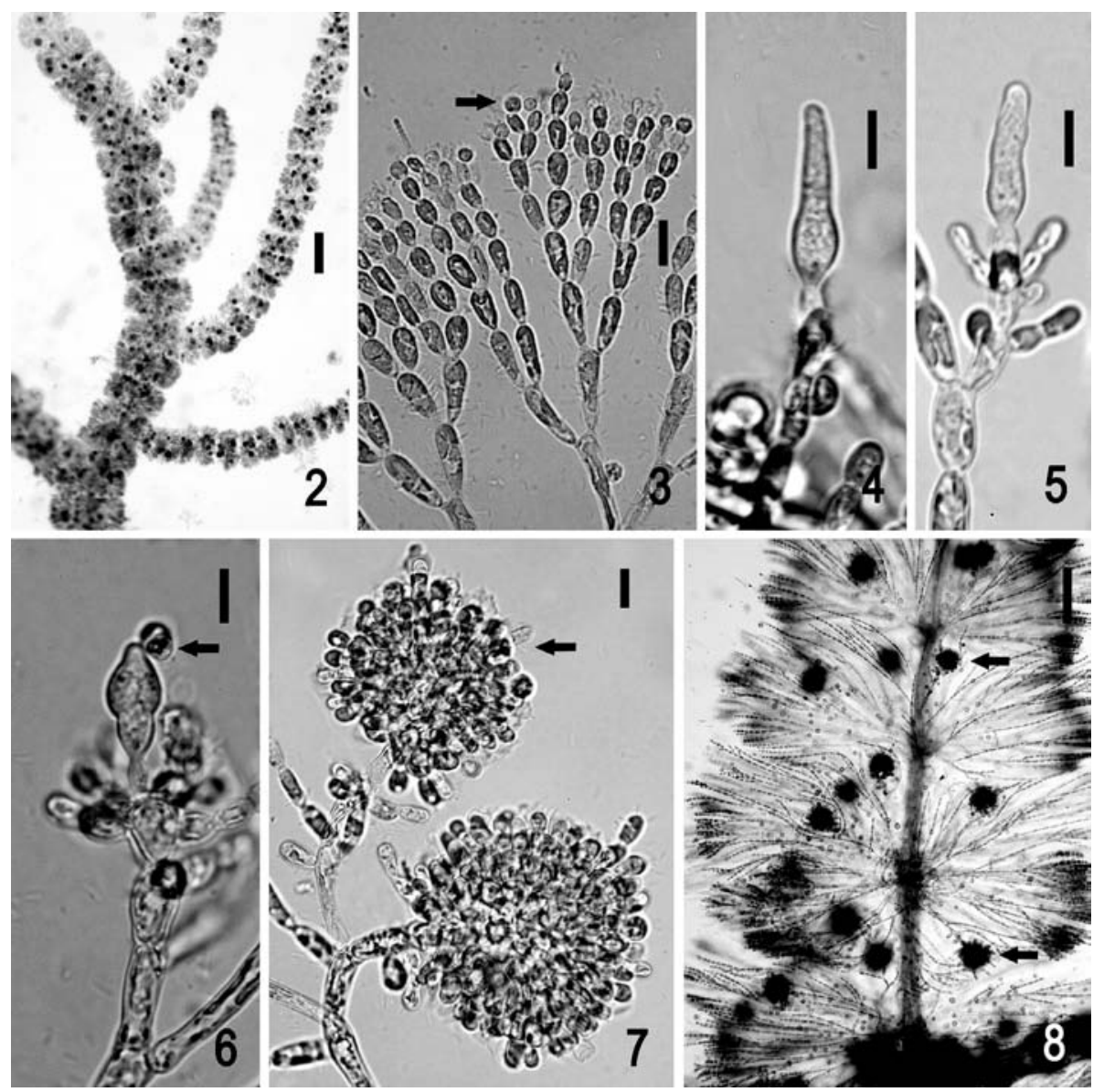

Figures 2-8. Morphological features of Batrachospermum gelatinosum. Fig. 2. Habit of alga. Fig. 3. Spermatangia (arrow) at fascicle branch tip. Fig. 4. Carpogonium-bearing branch with a club-shaped cell and lanceolated trichogynes. Fig. 5. Carpogonium with a cylindrical, stalked trichogyne. Fig. 6. Fertilized carpogonium with attached spermatium (arrow). Fig. 7. Carposporophyte with carposporangia (arrow). Fig. 8. Main axis with whorls and numerous carposporophytes (arrows). Scale bars: $100 \mu \mathrm{m}$ for Figs. 2 and 8; $10 \mu \mathrm{m}$ for Figs 3-7. Características morfológicas de Batrachospermum gelatinosum. Fig. 2. Aspecto del alga. Fig. 3. Espermatangios en el ápice de los filamentos verticilados (flecha). Fig. 4. Carpogonio redondo que nace en el ápice de una rama verticilada. Fig. 5. Carpogonio con un tricógino cilíndrico pedicelado. Fig. 6. Carpogonio fertilizado por un espermatangio (flecha). Fig. 7. Carposporofito con carposporas (flecha). Fig. 8. Eje principal con numerosos carposporofitos que nacen en las ramas verticiladas (flechas). Barra de escala: 100 m para Figs. 2 y 8; 10 um para figuras Figs. 3 a 7. 
termined using the equation: $n=(s / E \bar{x})^{2}$; where $s=$ standard deviation, $E=$ standard error $(0.05)$ and $\bar{x}=$ mean (Southwood, 1978).

\section{RESULTS AND DISCUSSION}

\section{Morphological analyses}

Batrachospermum gelatinosum (Linnaeus)

De Candolle (Figs. 2-8)

Monoecious algae, richly mucilaginous, 1.5$4 \mathrm{~cm}(\bar{x}=3 \mathrm{~cm})$ in length, whorls spherical or barrel-shaped, distant to confluent, 408-1060 $\mu \mathrm{m}$ $(\bar{x}=733 \mu \mathrm{m})$ in diameter; primary fascicles with 8-16 cell-storeys. Spermatangia hyaline, elliptical to spherical, $3-7.5 \mu \mathrm{m}(\bar{x}=5 \mu \mathrm{m})$ in diameter, one or two borne in distal cells of primary fascicles. Carpogonium born on an undifferentiated branch with 3-10 cells; carpogonium, 5-10 $\mu \mathrm{m}(\bar{x}=6 \mu \mathrm{m})$ in diameter, 21-39 $\mu \mathrm{m}$ $(\bar{x}=22 \mu \mathrm{m})$ in length, with cylindrical or lanceolated trichogynes, 5-8 $\mu \mathrm{m}(\bar{x}=6 \mu \mathrm{m})$ in diameter. Pedunculate, spherical carposporophyte, $50-160 \mu \mathrm{m}(\bar{x}=88 \mu \mathrm{m})$ in diameter; 3-9 carposporophytes exerted in the whorls at various distances from the axis. Gonimoblast filaments made of 2-4 cylindrical cells; spherical carposporangia, $7.5-12.5 \mu \mathrm{m}(\bar{x}=10 \mu \mathrm{m})$ in diameter. "Chantransia" stage not detected.

Phenology. Gametophytes were present in one locality in spring and summer with low percentage cover (3-5 \%) and evident reproductive maturity (i.e., abundant casposporophytes). This population was probably associated with the lowest current velocity $\left(5-50 \mathrm{~cm} \mathrm{~s}^{-1}\right)$ and temperate water $\left(12-13^{\circ} \mathrm{C}\right)$.

Iberian Peninsula distribution. Albacete, Barcelona, Girona, Jaén, Lleida, Murcia, (Aboal, 1989; Sabater et al., 1989); Castellón (Prefasi \& Aboal, 1994); Orense (López \& Peñalta, 2004).

Taxonomic remarks. The species is differentiated from other species of the section on the basis of monoecious algae and cylindrical cortical cells covering the main axis and rDNA internal transcribed space 1 and 2 sequences, RUBISCO large subunit gene data (Vis \& Sheath, 1998). These populations were similar to those in previous reports from deciduous forest populations in the southern USA and central Mexico (Vis et al., 1996; Carmona \& Vilaclara, 2007), but different from some dioecious populations of $B$. gelatinosum described by Aboal (1989). The great morphological variability shown in Spanish populations of Batrachospermum suggests the requirement of further molecular and life cycle studies.

\section{Lemanea fluviatilis (Linnaeus)}

C. Agardh (Figs. 9-16)

Gametophyte thallus is uniaxial and pseudoparenchymatous with stalked and definite constriction. Population scarcely branched (5\% of the population with one branched per individual) and $0.5-11 \mathrm{~cm}(\bar{x}=3 \mathrm{~cm})$ tall. Outer cortex composed of four cells layers; cells increasing significantly in size from outer to inner layers; axial filaments naked. Ray cell T- or L-shaped, closely applied to the cortex. Nodal diameter 294$686 \mu \mathrm{m}(\bar{x}=497 \mu \mathrm{m})$; internodal diameter 390$490 \mu \mathrm{m}(\bar{x}=435 \mu \mathrm{m})$; ratio nodal/internodal diameter 0.6-1.7 $(\bar{x}=1)$. Spermatangial sori in nodal patches; $161-242 \mu \mathrm{m}(\bar{x}=195 \mu \mathrm{m})$. Carpogonial branches composed of ovoid cells, penetrating the cortex towards the thallus surface; trichogyne pear-shaped. Carposporophyte sessile on the inner portion of cortex. Carpospores in chains of up to twelve, ovoid, 6-8 $\mu \mathrm{m}(\bar{x}=7 \mu \mathrm{m})$ in diameter. "Chantransia" stage microscopic, growing near the basis of gametophytic plants with cylindrical cells, $12-22 \mu \mathrm{m} \quad(\bar{x}=15 \mu \mathrm{m})$ diameter, $26-70 \mu \mathrm{m}$ $(\bar{x}=47 \mu \mathrm{m})$ length, without monosporangia.

Phenology. Gametophytes were present at the study site from spring to winter (Fig. 27). The highest percentage cover was registered in autumn and winter (38-41\%), corresponding to a decrease in water temperature $\left(5-7^{\circ} \mathrm{C}\right)$ and high current velocity $\left(58-80 \mathrm{~cm} \mathrm{~s}^{-1}\right.$ ). However, the gametophyte length, number of spermatangial sori and number of carpoporophytes were greatest in spring with high water temperature $\left(12-13^{\circ} \mathrm{C}\right)$ and low current velocity $\left(8-50 \mathrm{~cm} \mathrm{~s}^{-1}\right)$. The disappearance of the majority of gametophytes after 


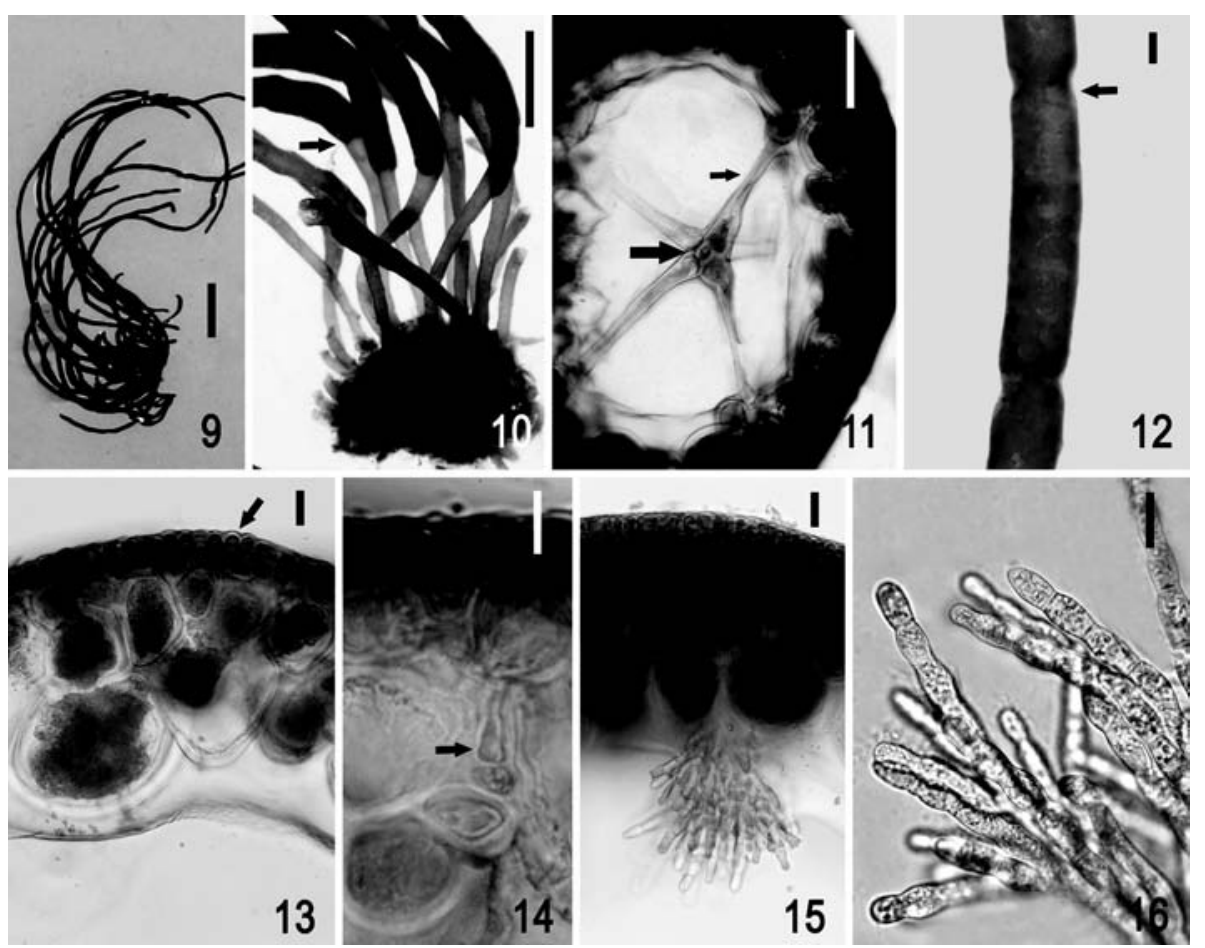

Figures 9-16. Morphological features of Lemanea fluviatilis. Fig. 9. Fig. 10. Basal system with stalked and definite constriction (arrow). Fig. 11. Cross section of the axial filament without interwoven medullar filaments (arrow) and ray cells (small arrow). Fig. 12. Spermatangial sori in nodal patches (arrow). Fig. 13. Cross section of a spermatangial cells (arrow). Fig. 14. Cross section of the cortex showing carpogonial branch (arrow). Fig. 15. Cross section showing the outer cortex with the carpogonium inside in the cavity. Fig. 16. Carpospores in chains. Scale bars: $1 \mathrm{~cm}$ for Figs. 9 and 10; $100 \mu \mathrm{m}$ for Figs. 11 and 12; $10 \mu \mathrm{m}$ for Figs. 1316. Características morfológicas de Lemanea fluviatilis. Fig. 9. Fig. 10. Sistema basal con una constricción bien definida (flecha). Fig. 11. Sección transversal del filamento axial con células de soporte (flecha) y células radiales (flecha pequeña). Fig. 12. Soros espermatangiales en forma de parche en la región nodal (flecha). Fig. 13. Detalle de las células espermatangiales en una sección tranversal del talo (flecha). Fig. 14. Corte transversal del cortex mostrando la rama carpogonial (flecha). Fig. 15. Sección transversal del talo mostrando el cortex y el carpogonio embebido en la cavidad. Fig. 16. Carposporas en cadenas. Barra de escala: $1 \mathrm{~cm}$ para Figs. 9 y 10; 100 m para Figs. 11 y 12; 10 um para Figs. 13-16.

the summer sampling corresponded with a reduction in water current and an increase in water temperature. Differences in the timing of open tips were consistent between seasons. Reproductive maturity (i.e., presence of carposporophytes) may be triggered by a temperature threshold $\left(\geq 12^{\circ} \mathrm{C}\right)$.

Iberian Peninsula distribution. Girona, Lleida (Tomas et al., 1987; Sabater et al., 1989); Orense (López \& Peñalta, 2004).

Taxonomic remarks. Lemanea fluviatilis is distinguished from other species of Lemanea by its stalked thallus, little-branched populations ( $<40 \%$ of the population), and patchy occurrence of spermatangia (Vis \& Sheath, 1992; Kučera \& Marvan, 2004).

\section{Paralemanea catenata (Kützing)}

Vis et Sheath (Figs. 17-26)

Uniaxial and pseudoparenchymatous gametophyte thallus, unstalked, without branching, 2$9.5 \mathrm{~cm}(\bar{x}=5 \mathrm{~cm})$ tall. Outer cortex composed of four cell layers; cells increasing significantly in size from outer to inner layers. Axial cell surrounded by abundant rhizoidal filaments. Ray cells form two layers: the proximal ones not touching the outer cortex, and the distal ones generally "Y"-branched and connected to the cortex. Nodal diameter 670-1570 $\mu \mathrm{m}(\bar{x}=962.8 \mu \mathrm{m})$; internodal diameter $430-970 \mu \mathrm{m}(\bar{x}=656.8 \mu \mathrm{m})$; ratio nodal/internodal diameter 1.0-2.5. Spermatangial sori in nodal rings; $65-102 \mu \mathrm{m}$ in di- 

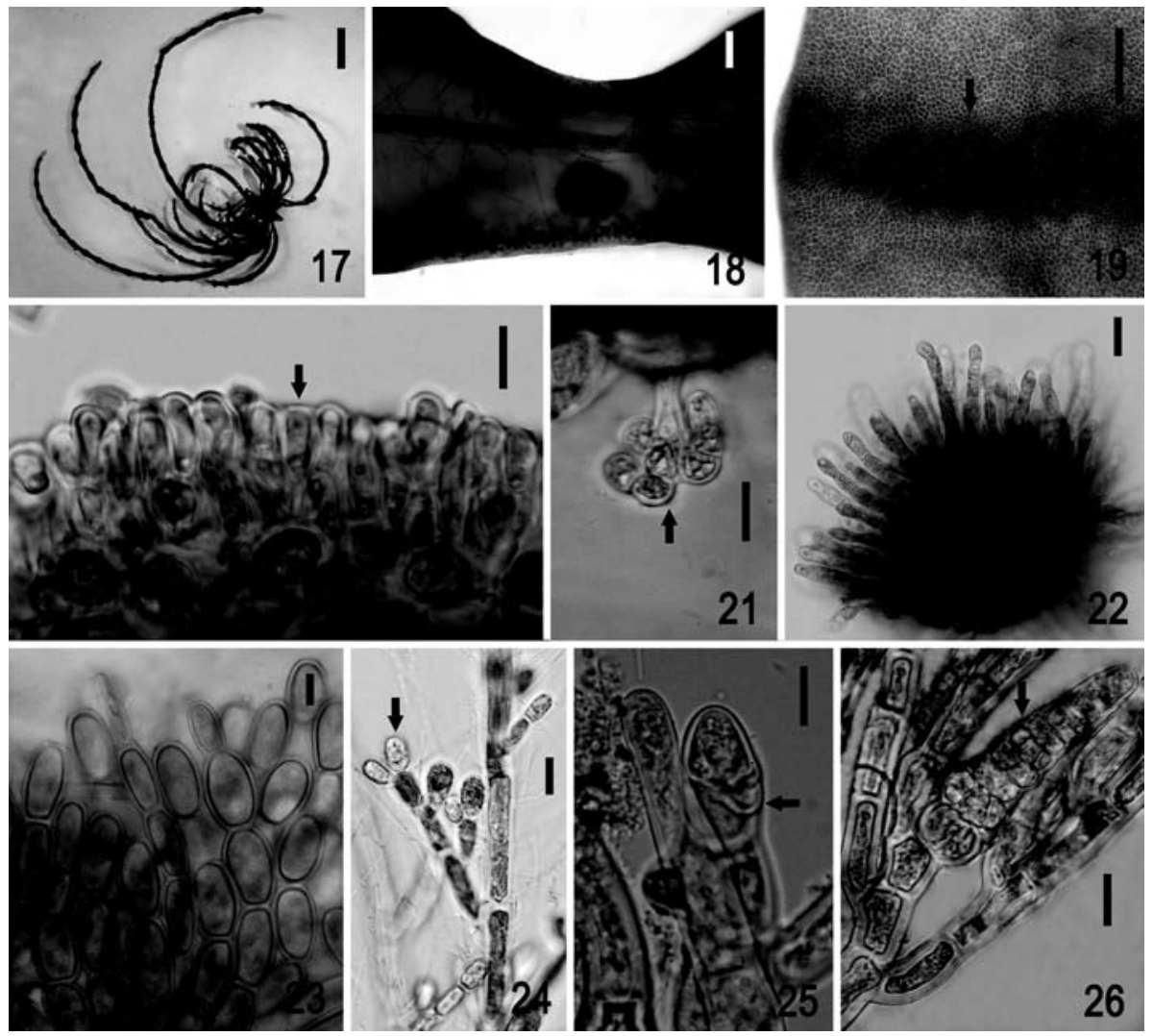

Figures 17-26. Morphological features of Paralemanea catenata. Fig. 17. Habit of alga. Fig. 18. Cross section of the thallus showing axial cell surrounded by abundant rhizoidal filaments (arrow). Fig. 19. Spermatangial sori in nodal rings (arrow). Fig. 20. Cross section of spermatangial cells (arrow). Fig. 21. Cross section of the outer cortex showing the gonimoblast filament (arrow). Fig. 22. Carposporangia inside the thallus cavity. Fig. 23. Carpospores in chains. Fig. 24. Detail of "Chantransia" stage and monosporangia (arrow). Fig. 25. Initial stage of meiosis in a "Chantransia" apical cell, showing a protrusion of the first elimination cell (arrow). Fig. 26. Early stage of the juvenile gametophyte (arrow). Scale bars: $1 \mathrm{~cm}$ for Fig. 17; $100 \mu \mathrm{m}$ for Figs. 18 and 19 ; $10 \mu \mathrm{m}$ for Figs. 20-26. Características morfológicas de Paralemanea catenata. Fig. 17. Aspecto del alga. Fig. 18. Corte del talo mostrando la célula axial rodeada de abundantes filamentos rizoidales (flecha). Fig. 19. Soros espematangiales en forma de anillo en la región nodal (flecha). Fig. 20. Detalle de las células espermatangiales en una sección transversal del talo (flecha). Fig. 21. Corte transversal del cortex exterior mostrando el filamento gonimoblástico (flecha). Fig. 22. Carposporangio dentro de la cavidad del talo. Fig. 23. Carposporas en cadenas. Fig. 24. Detalle de la fase "Chantransia” con monosporangios (flecha). Fig. 25. Célula de eliminación (flecha) que determina el estado inicial de la meiosis y se desarrolla en el ápice de una rama de la fase "Chantransia”. Fig. 26. Estadio

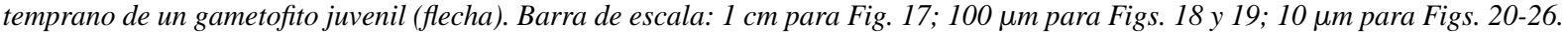

ameter; ratio spermatangial/nodal diameter 1 $1.9 \mu \mathrm{m}(\bar{x}=1.5 \mu \mathrm{m})$. Carpogonial branches composed of ovoid to globular cells, on nodes or internodes, and penetrating the cortex towards the thallus surface; trichogyne pearshaped. Carposporophyte sessile, on the inner portion of cortex. Carpospores in chains up to twelve, ovoid, ellipsoid or irregular, $10-17.5 \mu \mathrm{m}$ $(\bar{x}=14 \mu \mathrm{m})$ in diameter; $10-24 \mu \mathrm{m}(\bar{x}=21 \mu \mathrm{m})$ in length. "Chantransia" stage microscopic, brownish, growing near the base of the gameto- phytic thallus, with cylindrical cells, 15-22 $\mu \mathrm{m}$ $(\bar{x}=19 \mu \mathrm{m})$ diameter, $35-125 \mu \mathrm{m}(\bar{x}=73.5 \mu \mathrm{m})$ length and monosporangia spherical to subspherical, 14-18 $\mu$ m diameter. The "Chantransia" stage produced juvenile gametophytes in lateral branches of the "Chantransia" filament. The site of meiosis was generally situated one or two cells above a unilateral branching of the "Chantransia" filaments. The elimination cells are preserved during gametophyte development and can be observed even during the later stages. 
Phenology. Gametophytes were present in the study site from spring to winter (Fig. 28).

Generally, the mean gametophyte length, number of spermatangial sori and number of carpoporophytes were similar throughout the study. The highest percentage cover was reported in winter $(39 \%)$ and the longest gametophytes were found in spring in hightemperature water $\left(12-17^{\circ} \mathrm{C}\right)$ and low current velocity $\left(40-50 \mathrm{~cm} \mathrm{~s}^{-1}\right)$. The field data revealed an increase in the spring and summer of the percentage of open tips with abundant spermatangial sori and carposporohytes.

Iberian Peninsula distribution. Girona (as Lemanea nodosa, Sabater et al., 1989).

Taxonomical remarks. Paralemanea catenata is distinguished from Lemanea fluviatilis in Spain by its unstalked and unbranched thallus. Somatic meiosis in this population was similar to that observed in P. catenata from USA and other species of the Lemaneaceae (Necchi \& Carmona, 2002). The "Chantransia" stage was observed in the field, associated with the basal portion of gametophytes. The presence of monosporangia has rarely been reported in the "Chantransia" stage of Lemaneaceae but confirms that it represents a common mode of propagation, as in the order Batrachospermales (Sheath, 1984; Carmona \& Necchi, 2002).

\section{Ecology and distribution}

In terms of environmental variables (Table 1), all populations were found in conditions of mild temperature $\left(5-17^{\circ} \mathrm{C}\right)$, moderate acidity to neu-

Table 1. Physical and chemical characteristics of streams containing Batrachospermales in the Jarama Basin, Iberian Peninsula (DIN, dissolved inorganic nitrogen; SRP, soluble reactive phosphorus). $n=3$ for percentage cover, $n=10$ for current velocity, irradiance and depth, $n=3$ for physico-chemical analyses of water. Características físico-químicas de los ríos de la Cuenca del Jarama, Península Ibérica que contienen Batrachospermales (DIN, nitrógeno inorgánico disuelto, SRP, fósforo reactivo soluble). $\mathrm{n}=3$ para el porcentaje de cobertura, $\mathrm{n}=10$ para la velocidad de la corriente, irradiancia y profundidad. $\mathrm{n}=3$ para los análisis físico-químicos del agua.

\begin{tabular}{|c|c|c|c|c|c|c|c|c|c|c|c|c|}
\hline $\begin{array}{l}\text { Locality, season } \\
\text { and date }\end{array}$ & $\begin{array}{l}\text { Species and average } \\
\text { percentage cover }\end{array}$ & $\begin{array}{c}\mathrm{T} \\
{\left[{ }^{\circ} \mathrm{C}\right]}\end{array}$ & $\begin{array}{c}\text { Specific } \\
\text { conductance } \\
{\left[\mu \mathrm{S} \mathrm{cm}^{-1}\right]}\end{array}$ & & $\begin{array}{l}\text { Saturation } \\
\text { oxygen } \\
{[\%]}\end{array}$ & $\begin{array}{c}\mathrm{DIN} \\
{\left[\mathrm{mgl}^{-1}\right]}\end{array}$ & $\begin{array}{c}\mathrm{SRP} \\
{\left[\mathrm{mgl}^{-1}\right]}\end{array}$ & $\begin{array}{c}\mathrm{Ca}^{++} \\
\text {hardness } \\
{\left[\mathrm{mg} \mathrm{CaCO}_{3} 1^{-1}\right]}\end{array}$ & $\begin{array}{l}\text { Current } \\
\text { velocity } \\
{\left[\mathrm{cm} \mathrm{s}^{-1}\right]}\end{array}$ & $\begin{array}{l}\text { Irradiance } \\
{\left[\mu \mathrm{E} \mathrm{m}^{2} \mathrm{~s}^{-1}\right]}\end{array}$ & $\begin{array}{r}\text { Depth } \\
{[\mathrm{cm}]}\end{array}$ & $\begin{array}{l}\text { Associated } \\
\text { species }^{a}\end{array}$ \\
\hline \multicolumn{13}{|l|}{ Guadalix 1} \\
\hline $\begin{array}{l}\text { Spring } \\
25.04 .2008\end{array}$ & $\begin{array}{l}\text { Batrachospermum } \\
\text { gelatinosum (3) } \\
\text { Lemanea fluviatilis (20) }\end{array}$ & 12 & 72 & 6.3 & 100 & 0.28 & 0.04 & 15 & 50 & 83 & 13 & $\begin{array}{l}\text { Chamaesiphon } \\
\text { incrustans Grunow } \\
\text { in Rabenhorst [E] }\end{array}$ \\
\hline $\begin{array}{l}\text { Summer } \\
30.07 .2008\end{array}$ & $\begin{array}{l}\text { B. gelatinosum (5) } \\
\text { L. fluviatilis (1) }\end{array}$ & 13 & 108 & 6.6 & 96 & 0.83 & 0.04 & 15 & 8 & 67 & 4 & $\begin{array}{l}\text { Ch. incrustans }[\mathrm{E}] \\
\text { Hydrococcus caesatii } \\
\text { Rabenhorst [Eph] }\end{array}$ \\
\hline $\begin{array}{l}\text { Autumn } \\
07.11 .2008\end{array}$ & $\begin{array}{l}\text { B. gelatinosum }(0) \\
\text { L. fluviatilis }(38)\end{array}$ & 9 & 93 & 6.7 & 97 & 0.20 & 0.12 & 17 & 80 & 296 & 6 & Ch. incrustans $[\mathrm{E}]$ \\
\hline $\begin{array}{l}\text { Winter } \\
20.02 .2009\end{array}$ & $\begin{array}{l}\text { B. gelatinosum }(0) \\
\text { L. fluviatilis }(41)\end{array}$ & 7 & 91 & 7 & 100 & 0.38 & 0.13 & 15 & 58 & 723 & 11 & Ch. Incrustans $[\mathrm{E}]$ \\
\hline \multicolumn{13}{|l|}{ Guadalix 2} \\
\hline $\begin{array}{l}\text { Spring } \\
25.04 .2008\end{array}$ & Paralemanea catenata (19) & 12 & 120 & 7.2 & 102 & 0.79 & 0.23 & 19 & 50 & 800 & 7 & Stigeoclonium sp. [E] \\
\hline $\begin{array}{l}\text { Summer } \\
30.07 .2008\end{array}$ & P. catenata $(10)$ & 17 & 279 & 6.7 & 97 & 2.07 & 0.98 & 41 & 40 & 740 & 32 & H. caesatii [Eph] \\
\hline $\begin{array}{l}\text { Autumn } \\
05.12 .2008\end{array}$ & P. catenata $(20)$ & 7 & 197 & 7.5 & 101 & 0.42 & 0.53 & 29 & 62 & 79 & 17 & H. caesatii $[\mathrm{Eph}]$ \\
\hline $\begin{array}{l}\text { Winter } \\
27.02 .2008\end{array}$ & P. catenata (39) & 5 & 152 & 7.3 & 100 & 0.06 & 0.19 & 59 & 130 & 1132 & 6 & Stigeoclonium sp. [E] \\
\hline $\begin{array}{l}\text { Manzanares } \\
\text { Summer } \\
22.07 .2010\end{array}$ & L. fluviatilis (20) & 13 & 27 & 7.0 & 98 & 0.19 & 0.02 & 4 & 50 & 160 & 10 & Vaucheria sp. [E] \\
\hline $\begin{array}{l}\text { Mediano } \\
\text { Summer } \\
22.07 .2010\end{array}$ & L. fluviatilis (30) & 13 & 25 & 6.9 & 101 & 0.08 & 0.01 & 4 & 25 & 80 & 5 & Phormidium sp. [E] \\
\hline
\end{tabular}

$a=[$ E] Epilithic. [Eph] Epiphytic. 


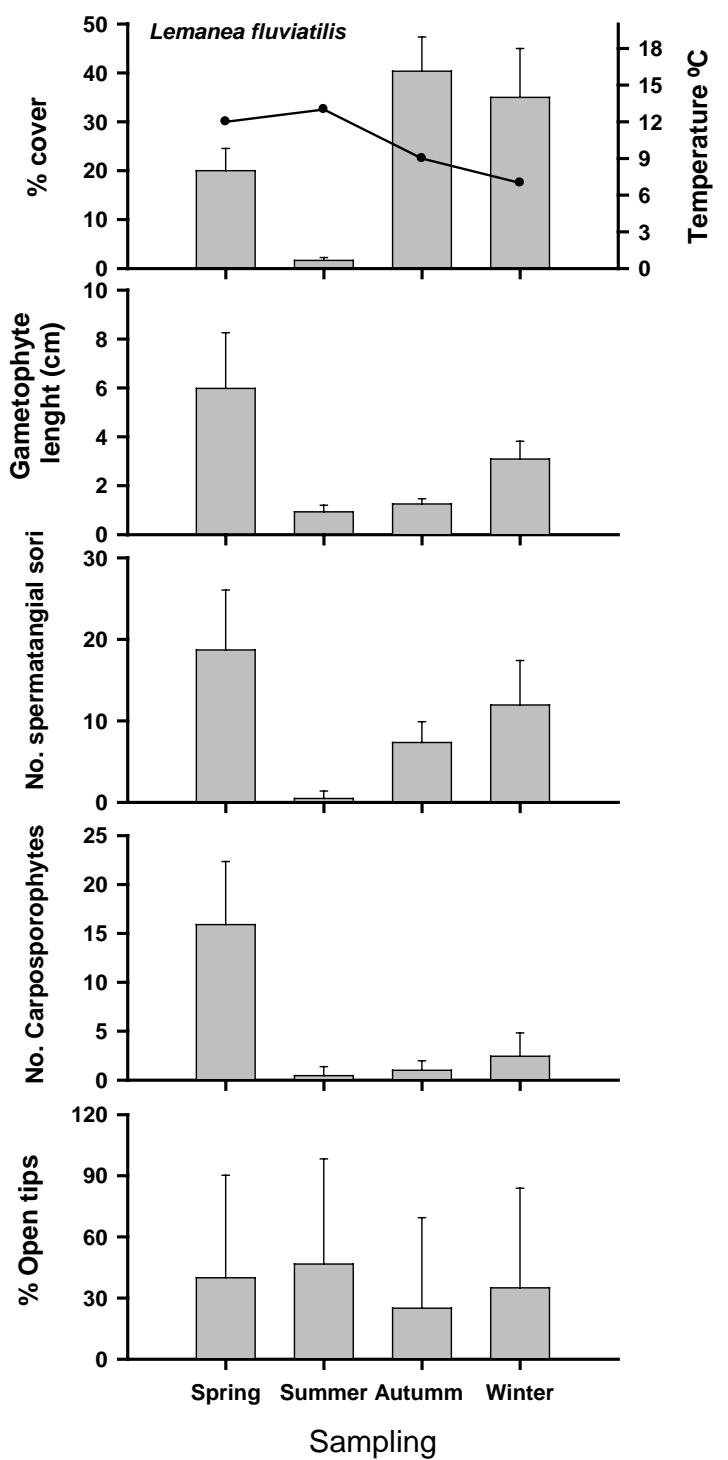

Figure 27. Percentage cover and values of reproductive characteristics (mean and standard deviation) for seasonal samples of Lemanea fluviatilis in Guadalix 1 location, Jarama Basin $n=3$ for percentage cover, and reproductive characteristics. $n=20$. Cobertura porcentual y valores de las características reproductoras (promedio y desviación estándar) de Lemanea fluviatilis durante el estudio estacional en el punto Guadalix 1, cuenca del Jarama. Para el porcentaje de cobertura $\mathrm{n}=3$, características reproductivas $\mathrm{n}=20$.

tral $\mathrm{pH}(6.3-7.5)$, relatively low ionic content (specific conductance $25-279 \mu \mathrm{S} \mathrm{cm}$ ), shallowness (depth 4-32 cm), and slow to fast water flow $\left(8-130 \mathrm{~cm} \mathrm{~s}^{-1}\right)$. The stream segment where it was observed is partly shaded, on rocky sub- strata (mostly bedrock), with a high percentage of oxygen saturation (96-101\%) and low hardness $\left(\leq 59 \mathrm{mg} \mathrm{CaCO}_{3} \mathrm{l}^{-1}\right)$. Temperatures were highly variable and similar to those reported by Vis et al. (1996) for B. gelatinosum $\left(1-27^{\circ} \mathrm{C}\right)$, Vis \& Sheath (1992) and Kučera \& Marvan (2004) for L. fluviatilis $\left(7-24^{\circ} \mathrm{C}\right.$ ) and P. catenata $\left(8-24^{\circ} \mathrm{C}\right)$. However, this study has demonstrated a clear relation between percentage cover and seasonal changes in the L. fluviatilis and $P$. catenata populations in the Guadalix segments, and a clear relationship with temperature (Figs. 27-28). The greatest percentage cover in the two streams was registered in autumn and winter, when temperatures were low $\left(5-9^{\circ} \mathrm{C}\right)$, similar to previous reports for $L$. fluviatilis in northeastern Spain (Tomas et al., 1987) and North America (Thirb \& Benson-Evans, 1985; Filkin \& Vis, 2004). Current velocity was positively associated with percentage cover in L. fluviatilis and $P$. catenata, suggesting it was also important. The current velocities measured in our study sites produce an optimal growth of L. fluviatilis from $80-200 \mathrm{~cm} \mathrm{~s}^{-1}$ similar to previous reports for this specie (Thirb \& Benson-Evans, 1985; Kučera et al., 2008). The moderate to highly alkaline waters reported for several sites with monoecious populations of $B$. gelatinosum $(=B$. moniliforme) in southeastern Spain (Sabater et al., 1989) contrast with the relatively acid and siliceous streams in this study. According to Vis \& Sheath (1992) and Eloranta \& Kwandrans (2002, 2004) this species has the widest range of distribution in North America and Europe, which could be due to a greater tolerance of conditions. In relation to the trophic level, we recognize two main groups, the first (Guadalix 1, Mediano and Manzanares) with populations of B. gelatinosum and L. fluviatilis growing in oligotrophic to mesotrophic conditions (soluble reactive phosphorous, SRP, 0.01-0.13 $\mathrm{mg} \mathrm{l}^{-1}$ and dissolved inorganic nitrogen, DIN, $0.08-0.83 \mathrm{mg} \mathrm{l}^{-1}$ ). The second group (Guadalix 2), with populations of $P$. catenata growing in more polluted, mesotrophic to eutrophic conditions (SRP, 0.06-0.32 $\mathrm{mg} \mathrm{l}^{-1}$ and DIN, 0.06-2.07 $\mathrm{mg} \mathrm{l}^{-1}$ ). These taxa, however, have a rather wide tolerance of physical and chemical variables (Vis \& Sheath, 1992; Elo- 


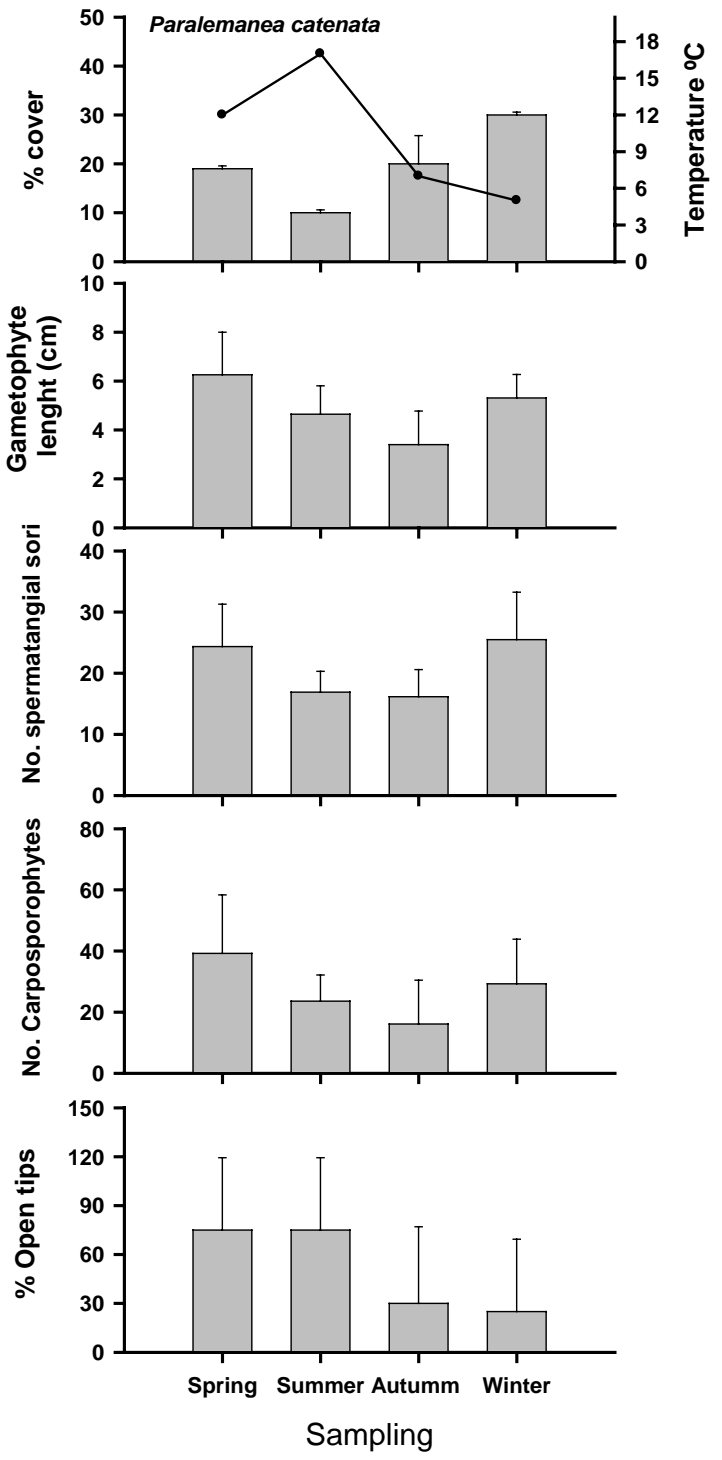

Figure 28. Percentage cover and values of reproductive characteristics (mean and standard deviation) for seasonal samples of Paralemanea catenata in Guadalix 2 location, Jarama Basin. $n=3$ for percentage cover and reproductive characteristics $n=20$. Cobertura porcentual y valores de las características reproductoras (promedio y desviación estándar) de Paralemanea catenata durante el estudio estacional en el punto Guadalix 2, cuenca del Jarama. Para el porcentaje de cobertura $\mathrm{n}=3$, características reproductivas $\mathrm{n}=20$.

ranta \& Kwandrans, 2002, 2004), and may be correlated with several morphological and reproductive adaptations. Lemanea fluviatilis and $P$. catenata were associated with two frequent and abundant epiphytic and epilithic Cyanobacteria, especially in the summer and autumn (Table 1):
Hydrococcus caesatii and Chamaesiphon incrustans (Serrano et al., 2004).

The affinities of Batrachospermales species in the Jarama Basin and the temperate streams in central and north Europe may indicate a possible biogeographical connection with the regions with temperate, boreal or high-altitude streams, e.g. Sweden (Israelson, 1942), Poland (Starmach, 1977; Mirek et al, 2006), Finland (Eloranta \& Kwandrans, 1996), Serbia and Montenegro (Cvijan, 2002; Simić 2007) and the Czech Republic (Lederer \& Soukupová, 2002; Kučera \& Marvan, 2004; Kučera et al., 2006, 2008). However, the genus Paralemanea is missing from northern Europe (Kwandrans \& Eloranta, 2010).

\section{ACKNOWLEDGEMENTS}

We also thank Phil Mason for linguistic revision of the manuscript. This work was supported by AECID (A/010529/07 and A/016417/08), MICINN (CGL 2008-02397BOS), CAM (P2009/AMB-1511) and UAM-SANTANDER (2009/10) grants to E. Perona and. J. Carmona.

\section{REFERENCES}

ABOAL, M. 1989. Contribución al conocimiento de las algas epicontinentales del SE de España II: Los rodófitos (Rhodophyceae). Lazaroa, 11: 115-122.

APHA. 1995. Standard Methods for the Examination of Water and Wastewater. $19^{\text {th }}$ ed. Washington, American Public Health Association. 1100 pp.

CARMONA, J. \& O. NECCHI JR. 2002. Taxonomy and distribution of Paralemanea (Lemaneaceae, Rhodophyta) in Central Mexico. Cryptogamie Algol., 23: 39-49.

CARMONA, J. \& F. G. VILACLARA. 2007. Survey and distribution of Batrachospermaceae (Rhodophyta) in high-altitude tropical streams from central Mexico. Cryptogamie Algo., 28: 271-282.

CARMONA, J., Z. G. MONTEJANO \& O. NECCHI JR. 2006. The ecology and morphological characterization of gametophyte and 'Chantransia' stages of Sirodotia huillensis (Batrachospermales, Rhodophyta) from a stream in central Mexico. Phycol. Res., 54: 108-115. 
CARMONA, J., M. BOJORGE, Y. BELTRÁN \& R. RAMÍREZ. 2009. Phenology of Sirodotia suecica (Batrachospermaceae, Rhodophyta) in a highaltitude stream in central Mexico. Phycol. Res., 57: 118-126.

CARRANZA, A. M. L. \& P. J. ARÍSTEGUI. 2002. Ríos de Madrid. Ed. Mundi-Prensa. Madrid. $167 \mathrm{pp}$.

CONFEDERACIÓN HIDROGRÁFICA DEL TAJO. 2009. Red de control biológico de la calidad del agua. (informe técnico 09-primavera-macrofitos 245 pp.) (http://www.chtajo.es/redes/Calidad/Aguas_ Superficiales/Red_Control_Calidad_Biologica/Resultados\%20Calidad_Biologica.htm)

COOMANS, R. J. \& M. H. HOMMERSAND. 1990. Vegetative growth and organization. In: Biology of the Red Algae. K. M. Cole \& R. G. Sheath (eds.): 275-304. Cambridge University Press. New York.

CVIJAN, M. 2002. Material for the algae flora of Serbia. II. Rhodophyta (Red algae). Arch. Biol. Sc. 54: $1-10$.

DOUTERELO, I., E. PERONA \& P. MATEO. 2004. Use of cyanobacteria to assess water quality in running waters. Environ. Pollut., 127: 377-384.

ELORANTA, P. \& J. KWANDRANS. 1996. Distribution and ecology of freshwater red algae (Rhodophyta) in some central Finnish rivers. Nord. J. Bot., 16: 107-117.

ELORANTA, P. \& J. KWANDRANS. 2002. Notes on some interesting freshwaters Rhodophyta from Findland. Arch. Hydrobiol. Suppl. Algol. Stud., 105: 95-109.

ELORANTA, P. \& J. KWANDRANS. 2004. Indicator value of freshwater red algae in running waters for quality assessment. Oceanol. Hydrobiol. Stud., 3: 47-54.

ENTWISLE, T. 1989. Psilosiphon scoparium gen. et. sp. nov. (Lemaneaceae), a new red algae from south-eastern Australia streams. Phycologia, 28: 469-75.

FILKIN, N. R. \& M. L.VIS. 2004. Phenology of Paralemanea annulata (Lemaneaceae, Rhodophyta) in an Ohio woodland stream. Hydrobiologia, 518: 159-168.

GASITH, A. \& V. H. RESH. 1999. Streams in Mediterranean climate regions: Abiotic influences and biotic responses to predictable seasonal events. Annu. Rev. Ecol. Syst., 30: 51-81.

GIBBSON, W. \& T. MORENO. 2006. The Geology of Spain. Geological Society Library Publisher. Southampton, UK. 632 pp.
HOLMGREN, P. K., N. H. HOLMGREN \& L. C. BARNETT. 1990. Index Herbariorum. Part. I. The Herbaria of the World. $8^{\text {th }}$ Edition. New York Botanical Garden, New York. 693 pp.

ISRAELSON, G. 1942. The freshwater Florideae of Sweden: studies on their taxonomy, ecology and distribution. Symb. Bot. Ups., 6: 1-135.

KUČERA, P. \& P. MARVAN. 2004. Taxonomy and distribution of Lemanea and Paralemanea (Lemaneaceae, Rhodophyta) in the Czech Republic. Preslia, 76: 163-174.

KUČERA, P., B. UHER \& O. KOMÁREK. 2006. Epiphytic cyanophytes Xenococcus kerneri and Chamaesiphon minitus on the freshwater red alga Paralemanea catenata (Rhodophyta). Biologia, 61: 11-13.

KUČERA, P., V. GRULICH, M. FRÁNKOVÁ \& P. BUREŚ. 2008. Distribution of freshwater red algal family Lemaneaceae (Rhodophyta) in the Czech Republic: an update. Fottea, 8: 125-128.

KUMANO, S. 1993. Taxonomy of the family Batrachospermaceae (Batrachospermales, Rhodophyta). Jap. J. Phycol., 41: 253-272.

KWANDRANS, J. \& P. ELORANTA (2010). Diversity of freshwater red algae in Europe. Oceanol. Hydrobiol. Stud., 34: 161-169.

LEDERER, F. \& L. SOUKUPOVÁ. 2002. Biodiversity and ecology of algae in mountains bogs (Bohemian Forests, Central Europe). Arch. Hydrobiol. Suppl. Algol. Stud., 78: 33-38.

LÓPEZ, M. C. \& M. PEÑALTA. 2004. Aportación al conocimiento de la flora ficológica del Macizo Central Gallego (N.O. España). An. Biología, 26: 79-91.

MIREK, Z., W. ZARZYCKI, Z. WOJEWODA \& Z. SZELAG. 2006. Red List of Plant and Fungi in Poland. Polish Academic of Sciences. Institute of Botany. Krakow, Poland. 99 pp.

NECCHI, O. JR., L. H. Z. BRANCO \& C. C. Z. BRANCO. 1995. Comparison of three techniques for estimating periphyton abundance in bedrock streams. Arch. Hydrobiol., 134: 393-402.

NECCHI, O. JR. \& J. CARMONA. 2002. Somatic meiosis and development of the juvenile gametophyte in members of the Batrachospermales sensu lato (Rhodophyta). Phycologia, 41: 340-347.

PREFASI, M. \& M. ABOAL. 1994. Estudio del género Batrachospermum Roth.: B. boryanum Sirod. y B. moniliforme Roth. en la provincia de Castellón, España. Acta Bot. Malacitana, 19: 45-50. 
REIS, P. M. 1954. Sur le Batrachospermum corbula Sirodot var. alcoense P. Reis n. var. Comm. VIII Congr. Int. Bot. Paris, 17eme Sect France: 70-71.

REIS, P. M. 1962a. Subsídios para o conhecimento da Rodofíceas de água doce de Portugal: III. Mem. Soc. Brot., 15: 57-71.

REIS, M. P. 1962b. Uma nova espécie de Lemanea Bory encontrada em Portugal. Bol. Soc. Brot., 36: 175-181.

REIS, P. M. 1965. Subsídios para o conhecimento da Rodofíceas de água doce de Portugal: V. Mem. Soc. Brot., 39: 137-156.

REIS, P. M. 1973. Subsídios para o conhecimento da Rodofíceas de água doce de Portugal: VIII. Mem. Soc. Brot., 47: 139-156.

SABATER, S., M. ABOAL \& J. CAMBRA. 1989. Nuevas observaciones de Rodofíceas en aguas epicontinentales del NE y SE de España. Limnetica, 5: 93-100.

SERRANO, A., P. MATEO \& E. PERONA. 2004. Estructura y composición de la comunidad de cianobacterias en un arroyo de montaña mediterráneo, el arroyo Mediano (Madrid). Limnetica, 23: 83-94.

SHEATH, R. G. 1984. The Biology of freshwater red algae. In: Progress in Phycological Research 3. F. E. Round \& D. J. Chapman (eds.): 89-157. Biopress Ltd.

SHEATH, R. G. \& J. A. HAMBROOK. 1990. Freshwater ecology. In: Biology of the Red Algae. M. K. Cole \& R. G. Sheath (eds): 423-453. Cambridge University Press. New York.

SHEATH, R. G., K. M. MÜLLER, M. L. VIS \& T. J. ENTWISLE. 1996. A re-examination of the morphology, ultrastructure and classification of genera in the Lemaneaceae (Batrachospermales, Rhodophyta). Phycol. Res., 4: 233-246.

SIMIĆ, S. 2007. Morphological and ecological characteristics of rare and endangered species Lemanea fluviatilis (Linné) C. AG. (Lemaneaceae,
Rhodophyta) on new localities in Serbia. Kragujevac J. Sci., 29: 97-106.

SOUTHWOOD, T. R. E. 1978. Ecological Methods, with Particular Reference to the Study of Insect Populations. Chapman \& Hall, New York. 524 pp.

STARMACH, K. 1977. Phaeophyta-Rhodophyta. Flora Slodkowodna Polski, 14. Polska akademia nauk, Warszawa. 444 pp.

THIRB, H. H. \& K. BENSON-EVANS. 1985. The effect of water temperature, current velocity and suspended solids on the distribution, growth and seasonality of Lemanea fluviatilis (C.Ag.) Rhodophyta, in the River Usk and other South Wales rivers. Hydrobiologia, 127: 63-78.

TOMAS, X., J. CAMBRA \& S. SABATER. 1987. Comunidades algales del Cabo de Creus (entre los 0 y $100 \mathrm{~m}$. de altitud) y su relación con el ambiente. Limnetica, 3: 111-119.

VIS, M. L. \& R. G. SHEATH. 1992. Systematics of the freshwater red algal family Lemaneaceae in North America. Phycologia, 31: 164-179.

VIS, M. L. \& R. G. SHEATH. 1996. Distribution and systematics of Batrachospermum (Batrachospermales, Rhodophyta) in North America. 9. Section Batrachospermum: description of five new species. Phycologia, 35: 124-134.

VIS, M. L. \& R. G. SHEATH. 1998. A molecular and morphological investigation of the relationship between Batrachospermum spermatoinvolucrum and B. gelatinosum (Batrachospermales, Rhodophyta). Eur. J. Phycol., 33: 231-239.

VIS, M. L., R. G. SHEATH \& T. ENTWISLE. 1995. Morphometric analysis of Batrachospermum (Batrachospermales, Rhodophyta) type specimens. Eur. J. Phycol., 30: 35-55.

VIS, M. L., R. G. SHEATH \& K. M. COLE. 1996. Distribution and systematics of Batrachospermum (Batrachospermales, Rhodophyta) in North America. 8a. Section Batrachospermum: Batrachospermum gelatinosum. Eur. J. Phycol., 3: 31-40. 